\title{
Transcription factor glioma-associated oncogene homolog 1 is required for transforming growth factor- $\beta 1$-induced epithelial-mesenchymal transition of non-small cell lung cancer cells
}

\author{
HUA LI*, LI-JUN DA*, WEI-DONG FAN, XIAO-HONG LONG and XIAN-QUAN ZHANG \\ Department of Oncology, The Second Affiliated Hospital, Chongqing Medical University, Chongqing 400010, P.R. China
}

Received February 10, 2014; Accepted November 19, 2014

DOI: $10.3892 / \mathrm{mmr} .2015 .3150$

\begin{abstract}
Epithelial-mesenchymal transition (EMT) is the process by which epithelial cells depolarize and acquire a mesenchymal phenotype, and is a common early step in the process of metastasis. Patients with lung cancer frequently already have distant metastases when they are diagnosed, highlighting the requirement for early and effective interventions to control metastatic disease. Transforming growth factor- $\beta 1$ (TGF- $\beta 1$ ) is able to induce EMT, however the molecular mechanism of this remains unclear. In the current study, TGF- $\beta 1$ was reported to induce EMT and promote the migration of non-small cell lung cancer (NSCLC) cells. A notable observation was that EMT induction was accompanied by the upregulation of human glioma-associated oncogene homolog 1 (Gli1) mRNA and protein levels. Furthermore, Gli1 levels were depleted by small interfering RNA, and the Gli1 inhibitor GANT 61 attenuated the TGF- $\beta 1$-mediated induction of EMT and cell migration. The results of the current study suggest that Glil regulates TGF- $\beta 1$-induced EMT, which may provide a novel therapeutic target to inhibit metastasis in patients with NSCLC.
\end{abstract}

\section{Introduction}

Lung cancer is the leading cause of cancer-associated mortality worldwide (1) and $~ 85 \%$ of cases of lung cancer are classified as non-small cell lung cancer (NSCLC) (2). Despite improvements in diagnostic and therapeutic strategies, the prognosis for patients with NSCLC remains poor, with a 5-year survival

Correspondence to: Professor Xian-Quan Zhang, Department of Oncology, The Second Affiliated Hospital, Chongqing Medical University, 76 Linjiang Road, Chongqing 400010, P.R. China

E-mail: xqzhng@hotmail.com

\section{*Contributed equally}

Key words: non-small cell lung cancer, transforming growth factor- $\beta 1$, human glioma-associated oncogene homolog 1 transcription factor, epithelial-mesenchymal transition rate of $8-14 \%$ (3). The primary cause of lung cancer-associated mortality is metastasis, and the majority of patients with NSCLC have begun to develop metastatic disease by the time they are diagnosed $(1,2)$. Thus, effective NSCLC therapies must include strategies to control metastatic disease. Such strategies may be improved by a more thorough understanding of the underlying mechanisms of NSCLC metastasis.

Epithelial-mesenchymal transition (EMT) is an early event in the metastatic progression of a number of types of epithelial cancer, such as lung cancer (4-10). EMT is the process by which epithelial cells transition from a typical epithelial phenotype (polarized and adherent) to a mesenchymal phenotype (spindle-shaped and motile). EMT results in clear alterations in the morphology, adhesive properties and gene expression of cells, including the upregulation of vimentin, $\mathrm{N}$-cadherin and fibronectin, in addition to the downregulation of E-cadherin and cytokeratin $(4,5)$. Additionally, the mesenchymal state during EMT is associated with a higher capacity for migration and invasion (11).

The process of EMT is regulated by a complex system of signal transduction pathways. One key regulator of EMT in lung cancer is the transforming growth factor- $\beta$ (TGF- $\beta$ ) signaling pathway $(11,12)$. In addition to TGF- $\beta$, the Hedgehog $(\mathrm{Hh})$ signaling pathway is known to participate in EMT, however the precise role of this pathway in EMT remains unclear (5). The Hh signaling pathway has been reported to be activated in a number of human tumors, including NSCLC and metastatic disease (13) and ultimately activates the transcription factor human glioma-associated oncogene homolog 1 (Gli1). Gli1 is also activated by other cancer-associated signaling pathways, such as the receptor tyrosine kinase and phosphoinositide 3-kinase (PI3K) pathways (14).

Despite its association with Hh signaling, the specific function of Gli1 in EMT remains to be fully elucidated. In the current study, the role of Gli1 in TGF- $\beta$-induced EMT was investigated in NSCLC cell lines. Gli1 levels in NSCLC cells that underwent TGF- $\beta 1$-induced EMT were measured, and the effect of small interfering RNA (siRNA)- or pharmacological agent-mediated inhibition of Gli1 activity on TGF- $\beta 1$-induced EMT was analyzed. To investigate this, alterations in morphology, phenotypic markers, invasion and migratory capability were measured. 


\section{Materials and methods}

Cell lines and reagents. The lung cancer cell lines A549, H460 and SK-MES-1 were purchased from the American Type Culture Collection (Manassas, VA, USA) and cultured in RPMI-1640 medium containing $10 \%$ fetal bovine serum (FBS) (Gibco Life Technologies, Carlsbad, CA, USA) at $37^{\circ} \mathrm{C}$ in a humidified atmosphere with $5 \% \mathrm{CO}_{2}$. Recombinant human TGF- $\beta 1$ and GANT 61 were purchased from PeproTech, Inc. (Rocky Hill, NJ, USA). Phase contrast images of A549 cells were acquired using an inverted phase contrast microscope (IX53; Olympus Corporation, Tokyo, Japan) subsequent to incubation of the cells with $0,1,5$ or $10 \mathrm{ng} / \mathrm{ml} \mathrm{TGF}-\beta 1$ for $48 \mathrm{~h}$. For western blot and immunofluorescent analysis, polyclonal rabbit anti-human Gli1 (ab49314), polyclonal rabbit anti-human E-cadherin (ab15148), monoclonal rabbit anti-human vimentin (ab16700), polyclonal rabbit anti-human $\beta$-actin (ab1801) and horseradish peroxidase (HRP)-conjugated anti-rabbit secondary antibodies were purchased from Abcam (Cambridge, MA, USA).

siRNA transfection and drug treatments. GFP-siRNA specific for Glil and nonspecific GFP-siRNA were diluted in diethylpyrocarbonate (DEPC)-treated water (all from Life Technologies, Grand Island, NY, USA). The siRNA was used to deplete Gli1 mRNA and protein levels in the A549 cells. A549 cells were transfected with DEPC-treated water (control group), a nonspecific control siRNA (si-VE group) or Gli1specific siRNA (si-Gli1 group). A549 cells were cultured until $60-70 \%$ confluence was reached and were then transfected with siRNA using X-tremeGENE siRNA (Roche Diagnostics, Basel,Switzerland) and OptiMEM medium (Life Technologies) according to the manufacturer's instructions. Following 6-h transfection, the cells were incubated in RPMI-1640 with $10 \% \mathrm{FBS}$ and $5 \mathrm{ng} / \mathrm{ml}$ TGF- $\beta 1$. At $24 \mathrm{~h}$ subsequent to transfection, the cells were imaged using the inverted phase contrast microscope to assess cell morphology, while transfection efficiency was assessed by detecting green fluorescent protein (GFP) fluorescence using a confocal laser-scanning microscope (OLS3100; Olympus, Corporation). Following a 48-h resting period, cells were collected for Transwell invasion assays, reverse transcription-quantitative polymerase chain reaction (RT-qPCR) and western blot analyses. For treatment with GANT 61, the H460 and SK-MES-1 cells were incubated with $10 \%$ FBS for $24 \mathrm{~h}$ and stimulated with $5 \mathrm{ng} / \mathrm{ml}$ TGF- $\beta 1$ for $48 \mathrm{~h}$ in the presence or absence of $10 \mu \mathrm{M}$ GANT 61.

RNA isolation and RT-qPCR. Total RNA from NSCLC cells was isolated using RNAiso Plus extraction reagent and cDNA was produced using PrimeScript Reverse Transcriptase (Takara Bio, Inc., Otsu, Japan) according to the manufacturer's instructions. RT-qPCR reactions were then conducted with SYBR Premix Ex Taq II (Takara Bio, Inc.) in $25 \mu$ l reactions with $2 \mu \mathrm{l}$ cDNA and $0.4 \mu \mathrm{M}$ each of the forward and reverse primers using the following thermocycling conditions: $95^{\circ} \mathrm{C}$ for $30 \mathrm{sec}, 95^{\circ} \mathrm{C}$ for $5 \mathrm{sec}$ and $60^{\circ} \mathrm{C}$ for $30 \mathrm{sec}$. Data was collected over 40 cycles and all expression levels were normalized to $\beta$-actin. The following primers were used: Gli1, F 5'-CTG GAC CTG CAG ACG GTT ATC-3' and R 5'-AGC CTC CTG GAG ATG TGC AT-3'; $\beta$-actin, F 5'-TGA CGT GGA CAT
CCG CAA AG-3' and R 5'-CTG GAA GGT GGA CAG CGA GG-3' (Sangon Biotech Co., Ltd., Shanghai, China).

Western blot analysis. For biochemical analysis, cells were washed with ice-cold phosphate-buffered saline (PBS; Beyotime Institute of Biotechnology, Jiangsu, China) and lysed in radioimmunoprecipitation assay lysis buffer [50mM Tris, $\mathrm{pH} 7.4 ; 150 \mathrm{mM} \mathrm{NaCl} ; 1 \%$ Triton X-100; $1 \%$ sodium deoxycholate; $0.1 \%$ sodium dodecyl sulfate (SDS); Beyotime Institute of Biotechnology]. The lysates were kept on ice for $30 \mathrm{~min}$ and clarified by centrifugation at $12,000 \mathrm{x} \mathrm{g}$ for $25 \mathrm{~min}$ at $4^{\circ} \mathrm{C}$. The clarified lysate was then collected and the vimentin, $\beta$-actin, E-cadherin and Gli1 proteins were separated by $12 \%$ SDS-polyacrylamide gel electrophoresis (30-100 $\mu \mathrm{g}$ protein/lane) and transferred to a polyvinylidine fluoride membrane (all from Beyotime Institute of Biotechnology). Subsequent to transfer, the membranes were incubated in $5 \%$ milk for $1 \mathrm{~h}$, and then with the Gli1 (2.5 $\mu \mathrm{g} / \mathrm{ml})$, E-cadherin (1:500), vimentin (1:500) or $\beta$-actin (1:1000) antibodies diluted in non-fat milk. The membranes were then washed with Tris-buffered saline with Tween-20 (Beyotime Institute of Biotechnology) and incubated with the HRP-conjugated secondary antibodies. Immunoreactive proteins were visualized using a BeyoECL Plus kit (Beyotime Institute of Biotechnology).

Immunofluorescence. For the immunofluorescence analysis, NSCLC cells were seeded onto glass slides $24 \mathrm{~h}$ prior to treatment and were transfected with TGF- $\beta 1$ and siRNA. Following treatment for $24 \mathrm{~h}$, cells were fixed with $4 \%$ paraformaldehyde (Beyotime Institute of Biotechnology) for $15 \mathrm{~min}$, washed with PBS, and permeabilized with $0.1 \%$ Triton X-100 (Beyotime Institute of Biotechnology) for $30 \mathrm{sec}$. To examine cell-surface expression of E-cadherin, the cells were not permeabilized following fixation. Cells were incubated with 5\% sheep serum albumin (Beyotime Institute of Biotechnology) for $1 \mathrm{~h}$ to block non-specific proteins. Subsequent to blocking, cells were incubated with the Gli1, E-cadherin, vimentin or $\beta$-actin antibodies, washed with PBS three times, and then incubated with fluorescein isothiocyanate-conjugated goat anti-rabbit and tetramethylrhodamine isothiocyanate-conjugated goat anti-rabbit secondary antibodies (ZF-0311; Zhongshan Golden Bridge Biotechnology Co., Ltd., Beijing, China) diluted in distilled water for $1 \mathrm{~h}$ at $37^{\circ} \mathrm{C}$. The stained cells were placed on a coverslip in mounting medium (Beyotime Institute of Biotechnology) with 4',6-diamidino-2-phenylindole (Beyotime Institute of Biotechnology) to label the nuclei. Cells were imaged using the OLS3100 fluorescence microscope (magnification, $\mathrm{x} 400$ ).

Transwell cell migration and invasion assay. The invasive and migratory ability of NSCLC cells was assessed using Matrigel-coated or uncoated chambers (Corning Incorporated, New York, NY, USA). At 48 h subsequent to transfection or GANT 61 (PeproTech, Inc.) treatment, $1 \times 10^{5}$ cells were seeded into the upper Transwell chamber, while the lower chamber was filled with RPMI-1640 supplemented with $20 \%$ FBS and $5 \mathrm{ng} / \mathrm{ml}$ TGF- $\beta 1$. The chambers were incubated at $37^{\circ} \mathrm{C}$ with $5 \% \mathrm{CO}_{2}$ for $24 \mathrm{~h}$. Cells on the upper surface of the filter were removed using a cotton swab, 
while cells that invaded/migrated to the lower surface of the filter were fixed with $4 \%$ paraformaldehyde for 15 min at room temperature, and stained with $0.1 \%$ crystal violet (Beyotime Institute of Biotechnology) for $30 \mathrm{~min}$. Crystal violet-stained cells were observed and images were captured under the phase contrast microscope, and counted in five randomly selected fields (magnification, x100). The experiments were performed in triplicate and each experiment was performed three times.

Wound healing cell migration assay. NSCLC cells were seeded into six-well plates and allowed to form confluent monolayers. The cell monolayers were scratched using a $200 \mu$ l pipette tip to create a wound, washed three times with PBS and incubated in RPMI-1640 supplemented with $0,1,5$ and $10 \mathrm{ng} / \mathrm{ml}$ TGF- $\beta 1$. Wound width was measured using phase contrast microscopy and images were captured immediately subsequent to the addition of TGF- $\beta 1(0 \mathrm{~h})$ and at $48 \mathrm{~h}$ of incubation.

Statistical analysis. Statistical analysis was conducted using SPSS, version 18.0 (SPSS, Inc., Chicago, IL, USA). All results are presented as the mean \pm standard deviation. Statistical analysis was performed using analysis of variance with the Tukey-Kramer post-hoc test. $\mathrm{P}<0.05$ was considered to indicate a statistically significant difference.

\section{Results}

TGF- $\beta 1$ induces EMT in NSCLC cells. Epithelial cancer cells undergo EMT early in the process of metastasis (15). A549 cells undergo EMT in response to TGF- $\beta 1$ exposure $(16,17)$, hence these cells can be used as a model to study EMT in NSCLC. To establish the role of TGF- $\beta 1$ in EMT, A549 cells were treated with $0,1,5$ or $10 \mathrm{ng} / \mathrm{ml}$ TGF- $\beta 1$ for $48 \mathrm{~h}$ and the morphological alterations occurring were assessed by phase contrast microscopy. The untreated A549 cells were observed to exhibit classic epithelial morphology, whereas subsequent to 48-h TGF- $\beta 1$ treatment, cell morphology was clearly altered. The cells acquired a mesenchymal phenotype, becoming elongated, spindle-shaped cells with reduced cell-cell contacts (Fig. 1A). The extent of these morphological alterations was dose-dependent for TGF- $\beta 1$, suggesting that the effects observed were a result of TGF- $\beta 1$ treatment.

The phenotypic alterations occuring suggested that A549 cells had undergone EMT, thus the expression of specific EMT markers, including the epithelial marker E-cadherin and the mesenchymal marker vimentin were measured (7,11). Following the treatment of A549 cells with a range of concentrations of TGF- $\beta 1$ for $48 \mathrm{~h}$, E-cadherin and vimentin expression was assessed by western blot analysis. TGF- $\beta 1$ treatment led to reduced expression of the E-cadherin and increased expression of the vimentin compared with the control, in a concentration-dependent manner (Fig. 1B). Similar results were obtained in the other NSCLC cell lines, with $5 \mathrm{ng} / \mathrm{ml}$ TGF- $\beta 1$-treatment of H460 and SK-MES-1 cells for $48 \mathrm{~h}$ resulting in increased expression levels of vimentin but a reduction in E-cadherin expression, compared with untreated cells (Fig. 1C and D). These data suggest that TGF- $\beta 1$ induces EMT in NSCLC cells.
The development of metastatic disease is the most frequent cause of cancer-associated mortality (18). EMT is often associated with metastasis, as the invasive and migratory capacity of cells increases following the induction of EMT. To analyze the migratory capacity of A549 cells following TGF- $\beta 1$ treatment, wound healing assays were conducted. In this assay, it was observed that TGF- $\beta 1$ treatment led to increased migration after $48 \mathrm{~h}$ compared with untreated cells (Fig. 1E). To assess the effect of TGF- $\beta 1$ on the invasive capacity of NSCLC cells, Transwell invasion assays were conducted using TGF- $\beta 1$-treated H460 and SK-MES-1 cells, which exhibited increased invasion compared with the control (Fig. 1F and G). These results indicate that TGF- $\beta 1$ induces enhanced migration and invasion of NSCLC cells, which is consistent with the observed phenotypic alterations. These data support an involvement of TGF- $\beta 1$ in the induction of EMT in NSCLC cells.

Upregulation of Glil expression levels in TGF- $\beta 1$-stimulated NSCLC cells. Gli1 is commonly observed to be overexpressed in NSCLC, and has been implicated in the induction of EMT and metastasis $(13,19-21)$. Therefore, the role of Gli1 was investigated in TGF- $\beta 1$-induced EMT. Using RT-qPCR and western blot analysis, it was observed that TGF- $\beta 1$ stimulation significantly increased Gli1 mRNA and protein levels in A549, H460 and SK-MES-1 cells, compared with untreated cells (Fig. 2A-D). A similar induction of Gli1 was observed in the immunofluorescence analysis of TGF- $\beta 1$-treated A549 cells (Fig. 2E). These results indicate that Gli1 upregulation occurs during TGF- $\beta 1$-induced EMT in NSCLC cells.

Effect of Glil-siRNA and GANT 61 treatment on Glil induction by TGF- $\beta 1$ in NSCLC cells. To determine the function of Gli1 in TGF- $\beta 1$-induced EMT, siRNA was used to deplete Gli1 mRNA and protein levels in A549 cells. The cells were transfected with DEPC-treated water (control), Gli1-specific siRNA (si-Gli) or nonspecific control siRNA (si-VE) for $24 \mathrm{~h}$. Fluorescence microscopy analysis indicated that the siRNAs were efficiently transfected, as demonstrated by the presence of GFP expression (Fig. 3A). Subsequent to a 48-h resting period, Gli1 mRNA expression levels were significantly suppressed by Gli1-specific siRNA compared with control, as measured by RT-qPCR $(\mathrm{P}<0.001$; Fig. 3B). This siRNA-mediated depletion of Gli1 was further confirmed by western blotting (Fig. 3C) and immunofluorescence analysis (Fig. 3D). As an alternative to siRNA-mediated depletion of Gli1, the effects of pharmacological inhibition of Gli1 were investigated using the Gli1-specific inhibitor GANT 61 in TGF- $\beta 1$-treated H460 and SK-MES-1 cells. Cells were treated with $10 \mu \mathrm{M}$ GANT 61 for $48 \mathrm{~h}$ prior to stimulation with $5 \mathrm{ng} / \mathrm{ml}$ TGF- $\beta 1$ for an additional $48 \mathrm{~h}$. This was demonstrated by RT-qPCR and western blot analysis to downregulate Gli1 mRNA and protein levels in the H460 $(\mathrm{P}<0.001)$ and SK-MES-1 $(\mathrm{P}<0.05)$ cell lines, compared with controls (Fig. 3E and F).

Effects of Gli1 inhibition on TGF- $\beta 1$-induced EMT of NSCLC cells. To determine if Gli1 participated in the induction of EMT in NSCLC cells, phase contrast microscopy was used to assess the morphology of A549 cells $24 \mathrm{~h}$ subsequent to si-Gli1, si-VE or blank transfection, and $18 \mathrm{~h}$ subsequent 

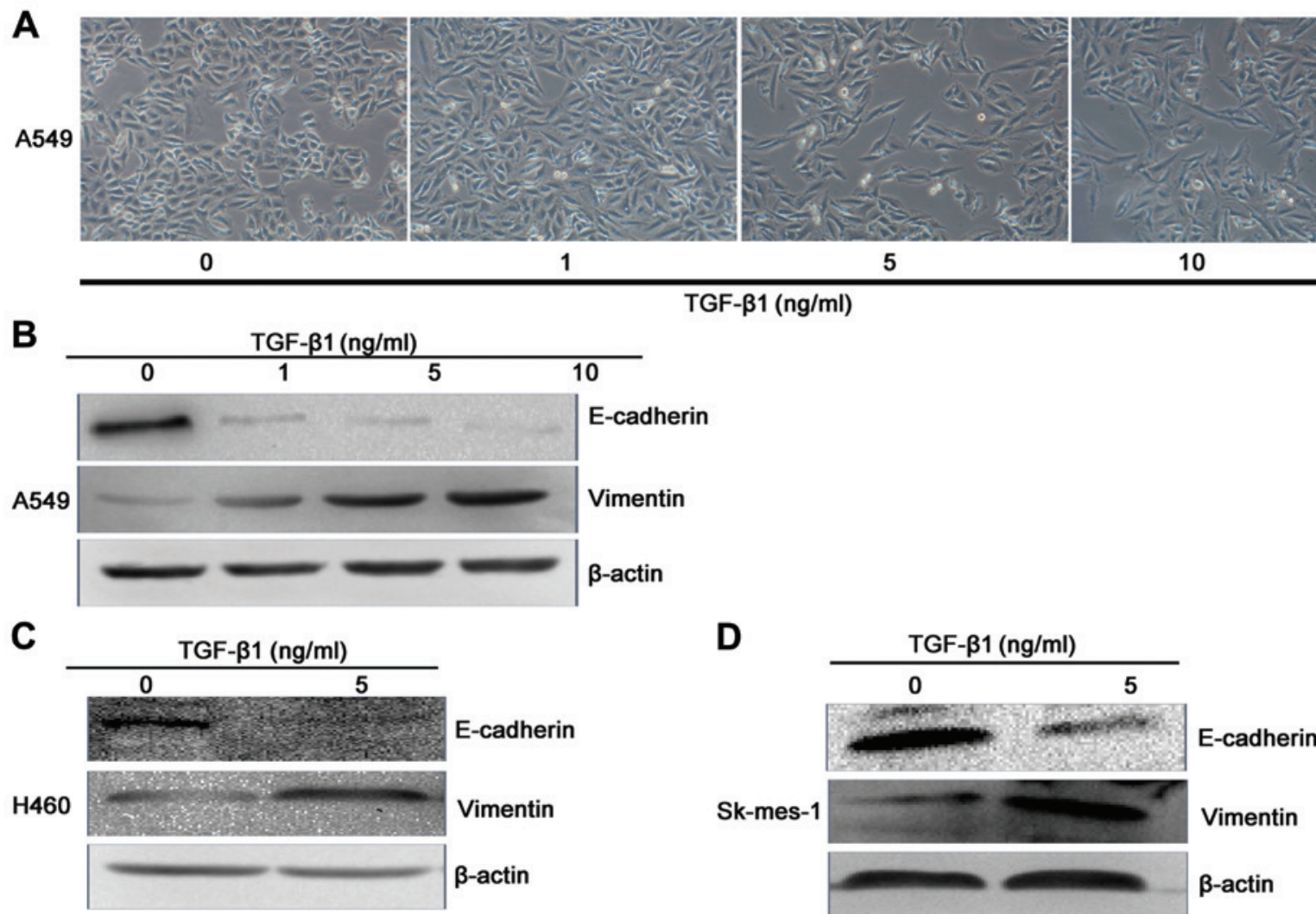

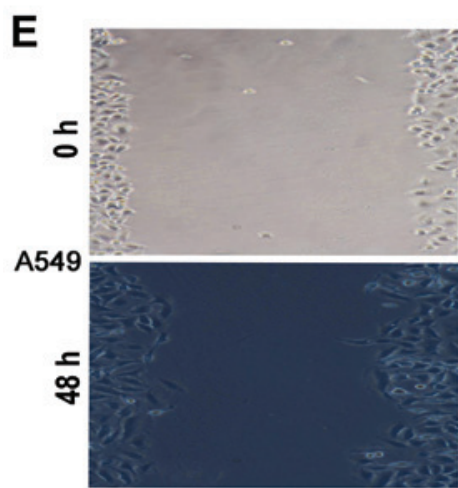

0

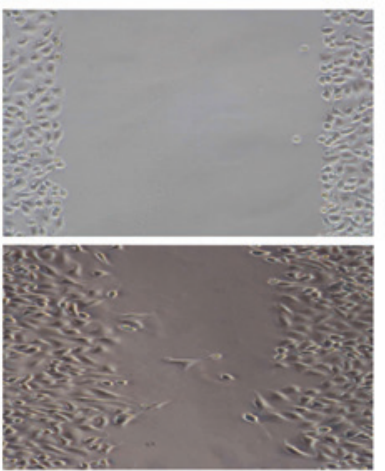

1

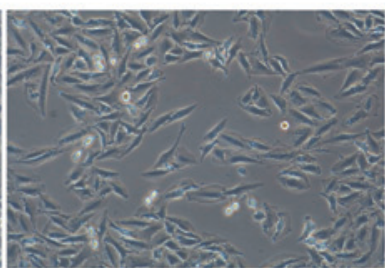

5

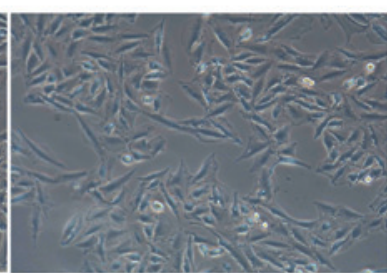

10

TGF- $\beta 1(\mathrm{ng} / \mathrm{ml})$

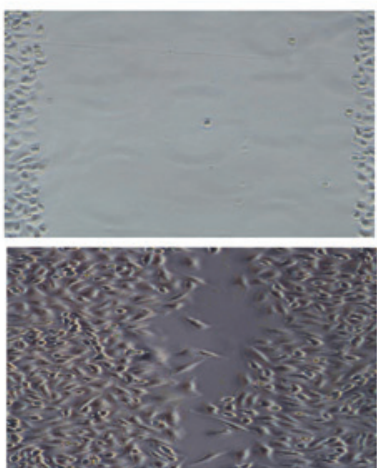

5

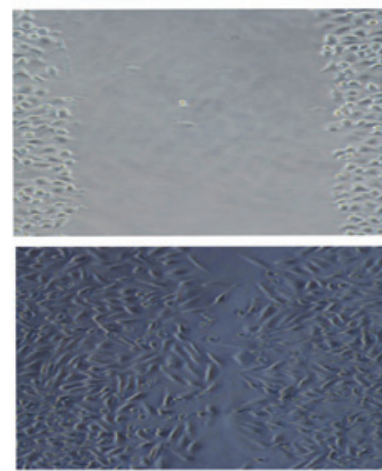

10

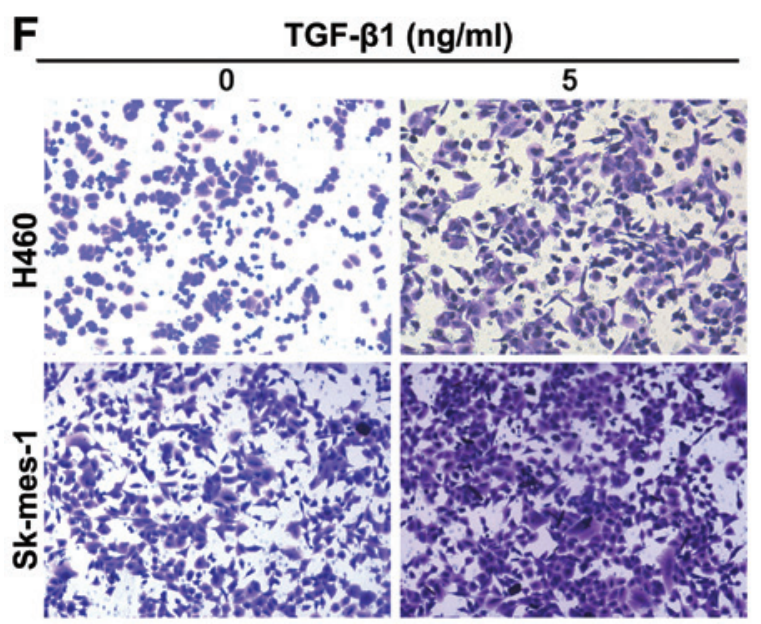

TGF- $\beta 1(\mathrm{ng} / \mathrm{ml})$

G

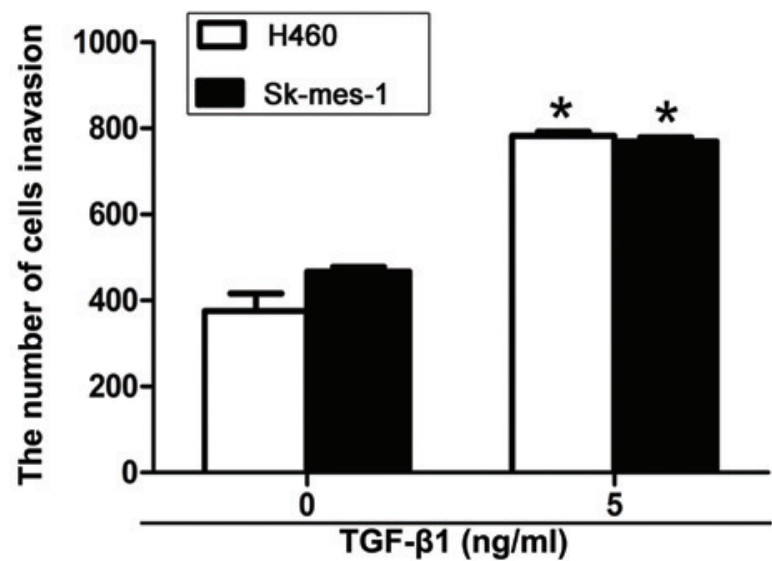

Figure 1. TGF- $\beta 1$-induced EMT in the A549 cell line. (A) Phenotypic alterations induced by treatment with $0,1,5 \mathrm{or} 10 \mathrm{ng} / \mathrm{ml}$ TGF- $\beta 1$ for $48 \mathrm{~h}$ (magnification, $\mathrm{x} 100)$. Western blot analysis to determine the protein levels of E-cadherin, vimentin and $\beta$-actin in (B) A549, (C) H460 and (D) SK-MES- 1 cells treated with TGF- $\beta 1$ for $48 \mathrm{~h}$. (E) The migratory capacity of A549 cells was assessed by a wound healing assay. Phase contrast microscope images captured at 0 and $48 \mathrm{~h}$ subsequent to TGF- $\beta 1$ treatment; magnification, x200. Transwell cell invasion assay to analyze the invasive capacity of H460 and SK-MES-1 cells treated with $5 \mathrm{ng} / \mathrm{ml}$ TGF- $\beta 1$ for $48 \mathrm{~h}$. Invasive cells were (F) imaged with crystal violet and (G) quantified. " $\mathrm{P}<0.05$ vs. control. TGF- $\beta 1$, transforming growth factor- $\beta 1$; EMT, epithelial-mesenchymal transition. 


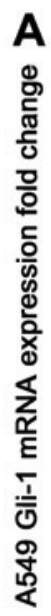

C

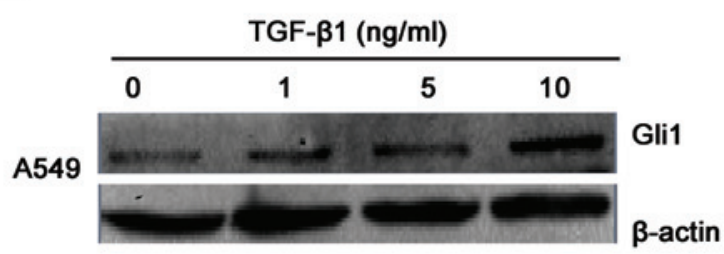

B

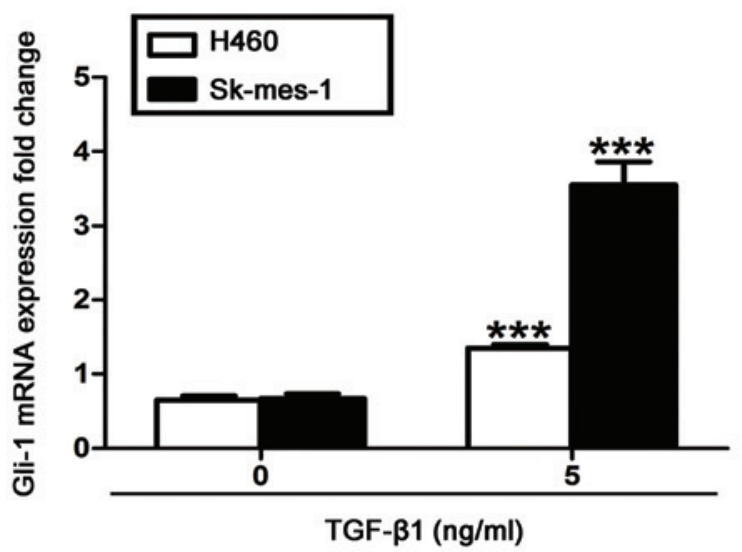

D

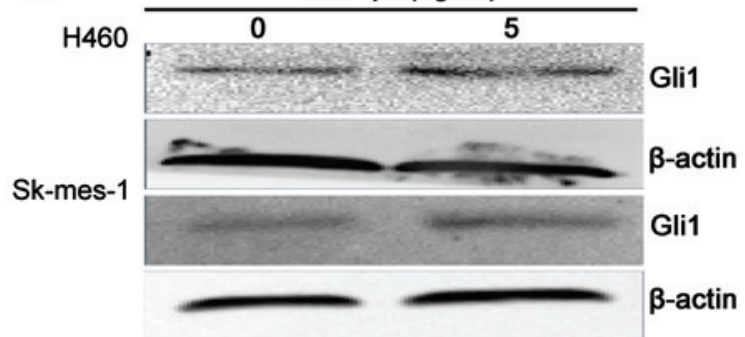

$\mathbf{E}$

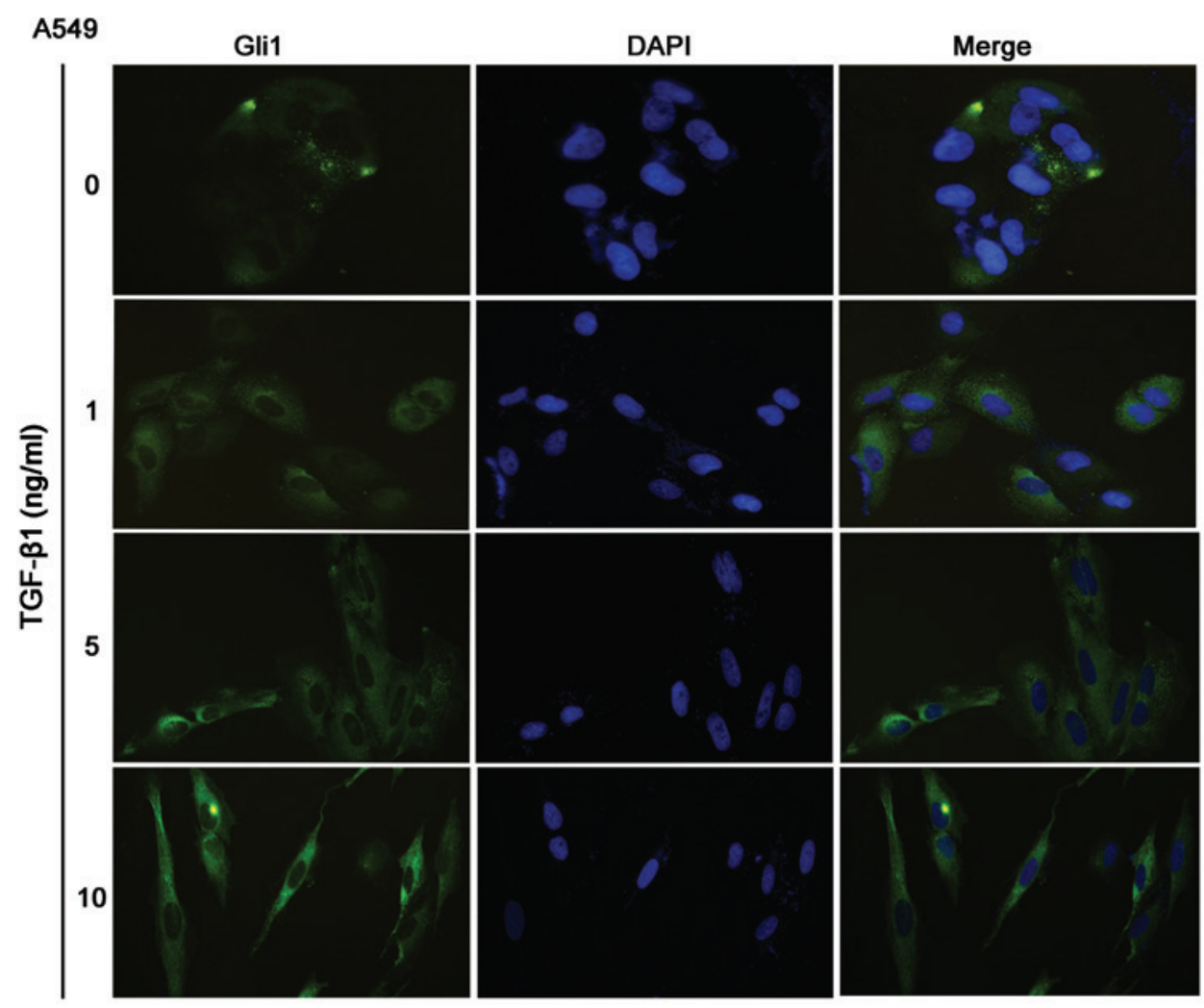

Figure 2. TGF- $\beta 1$-treated NSCLC cells demonstrated an upregulation of Gli1 mRNA and protein levels. Gli1 mRNA levels assessed by RT-qPCR in (A) A549 and (B) H460 and SK-MES-1 cells treated for $48 \mathrm{~h}$ with TGF- $\beta 1$. All values are presented as the mean, error bars represent the standard deviation, ${ }^{*} \mathrm{P}<0.05,{ }^{* *} \mathrm{P}<0.005$ and ${ }^{* * *} \mathrm{P}<0.001$ vs. control. Gli1 protein levels in (C) A549 and (D) H460 and SK-MES-1 cells stimulated with TGF- $\beta 1$ were examined using western blotting, with $\beta$-actin as a loading control. (E) Immunofluorescence staining (magnification, $x 400$ ). All experiments were performed 3 times. TGF- $\beta 1$, transforming growth factor- $\beta 1$; NSCLC, non-small cell lung cancer; Gli1, glioma-associated oncogene homolog 1; RT-qPCR, reverse transcription-quantitative polymerase chain reaction. 


\section{A $\quad$ A549}

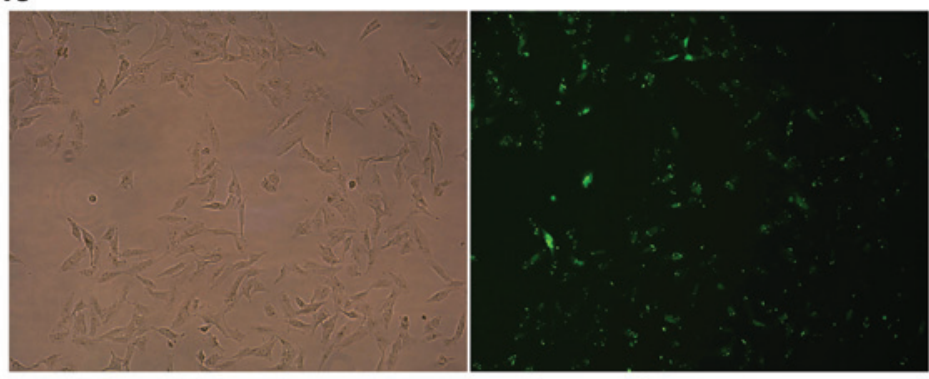

Phase contrast

Fluorescent

B

D $\quad$ A549

Gli1

DAPI

Merge
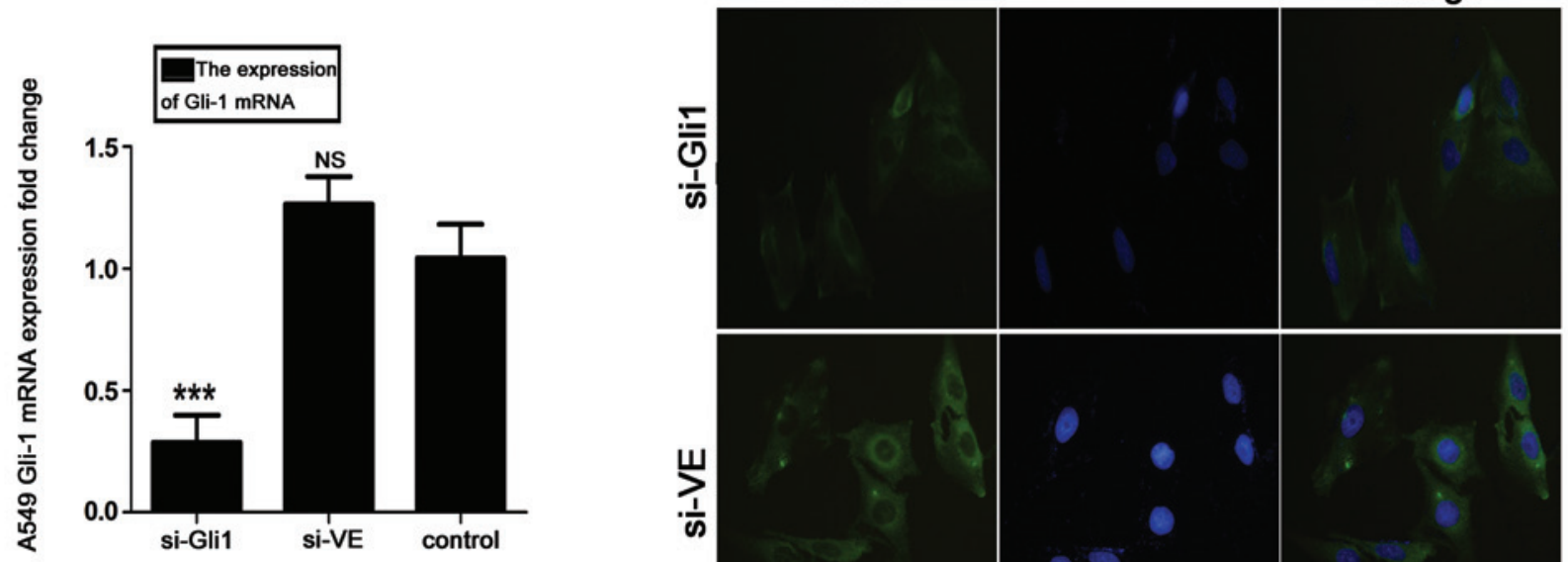

C
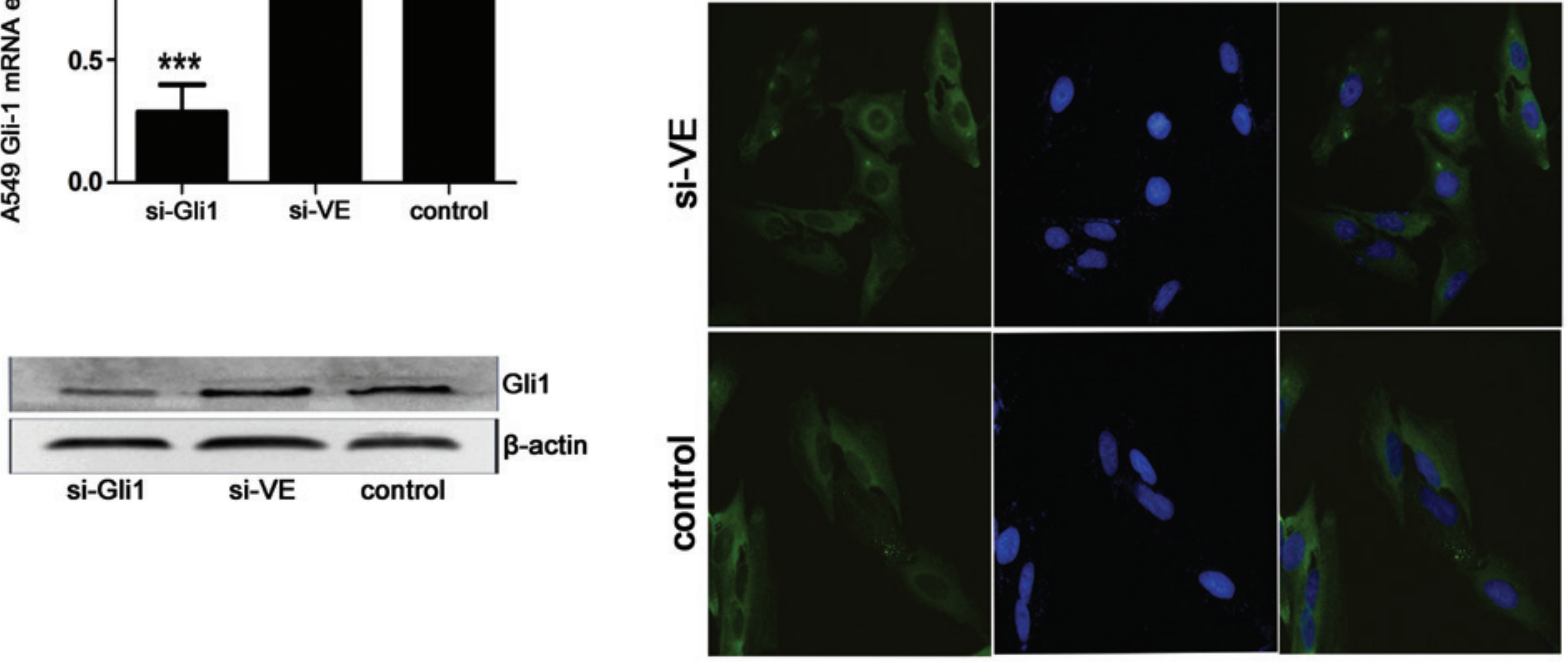

E

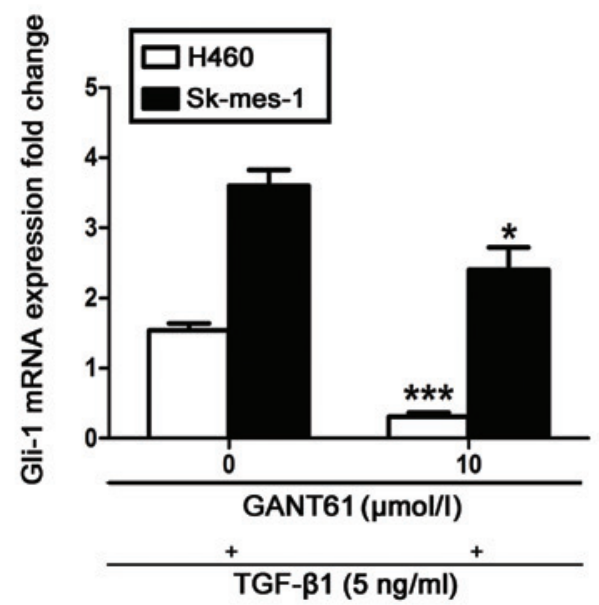

$\mathbf{F}$

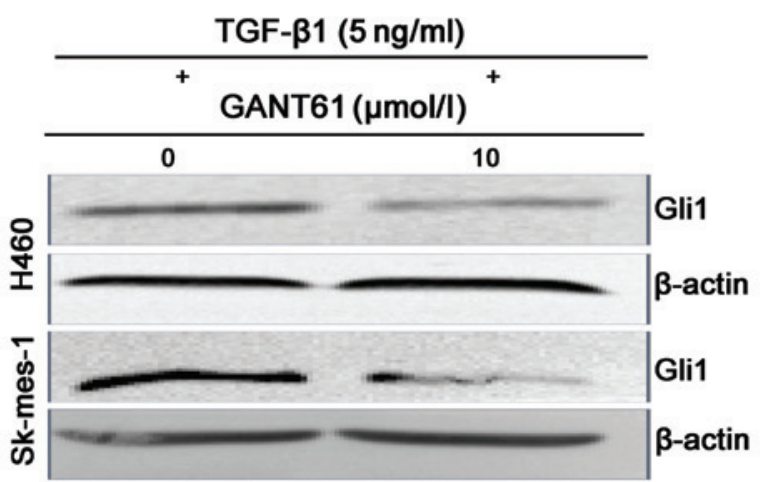

Figure 3. Effect of Gli1-siRNA and GANT 61 on Gli1 expression in TGF- $\beta 1$-induced NSCLC cells. (A) Confocal laser scanning microscope images to assess transfection efficiency. (B) Gli1 mRNA expression levels were assessed by RT-qPCR. (C) Western blot analysis of Gli1 protein expression in the si-Gli1, si-VE and control groups, with $\beta$-actin as the loading control. (D) Immunofluorescence staining (magnification, $\mathrm{x} 400$ ). All experiments were performed 3 times. (E) RT-qPCR assessment and (F) western blot analysis of H460 and SK-MES-1 cells treated with the Gli1 inhibitor GANT 61 (10 $\mu \mathrm{M})$ for $48 \mathrm{~h}$, followed by $48 \mathrm{~h}$ stimulation with TGF- $\beta 1$. All values are presented as the mean, error bars represent the standard deviation; NS, not significant, ${ }^{*} \mathrm{P}<0.05,{ }^{* * *} \mathrm{P}<0.005$ and ${ }^{* * *} \mathrm{P}<0.001$ vs. control. Gli1, glioma-associated oncogene homolog 1; si-Gli1, Gli1 siRNA group; si-VE, nonspecific siRNA group; TGF- $\beta 1$, transforming growth factor- $\beta 1$; NSCLC, non-small cell lung cancer; RT-qPCR, reverse transcription-quantitative polymerase chain reaction. 
A

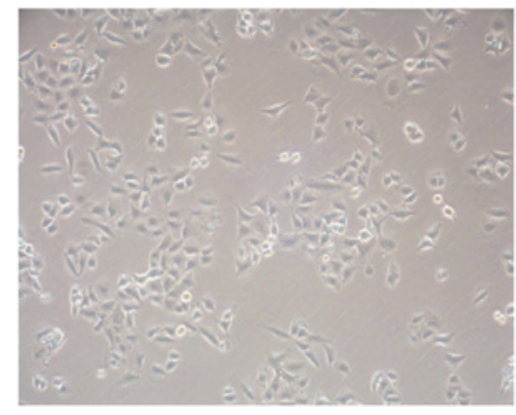

si-Gli1

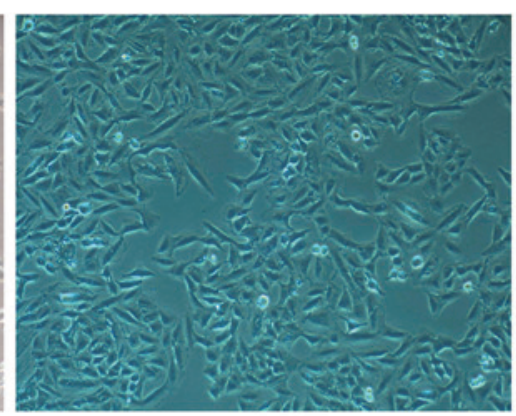

si-VE

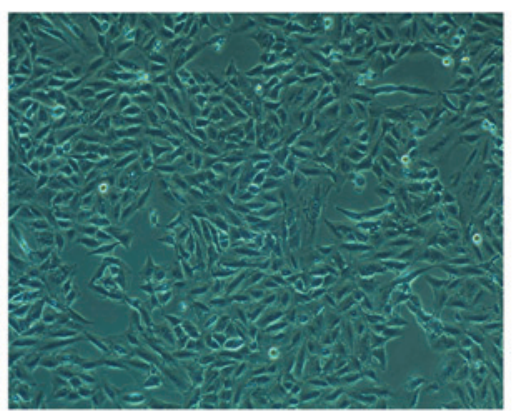

control

B
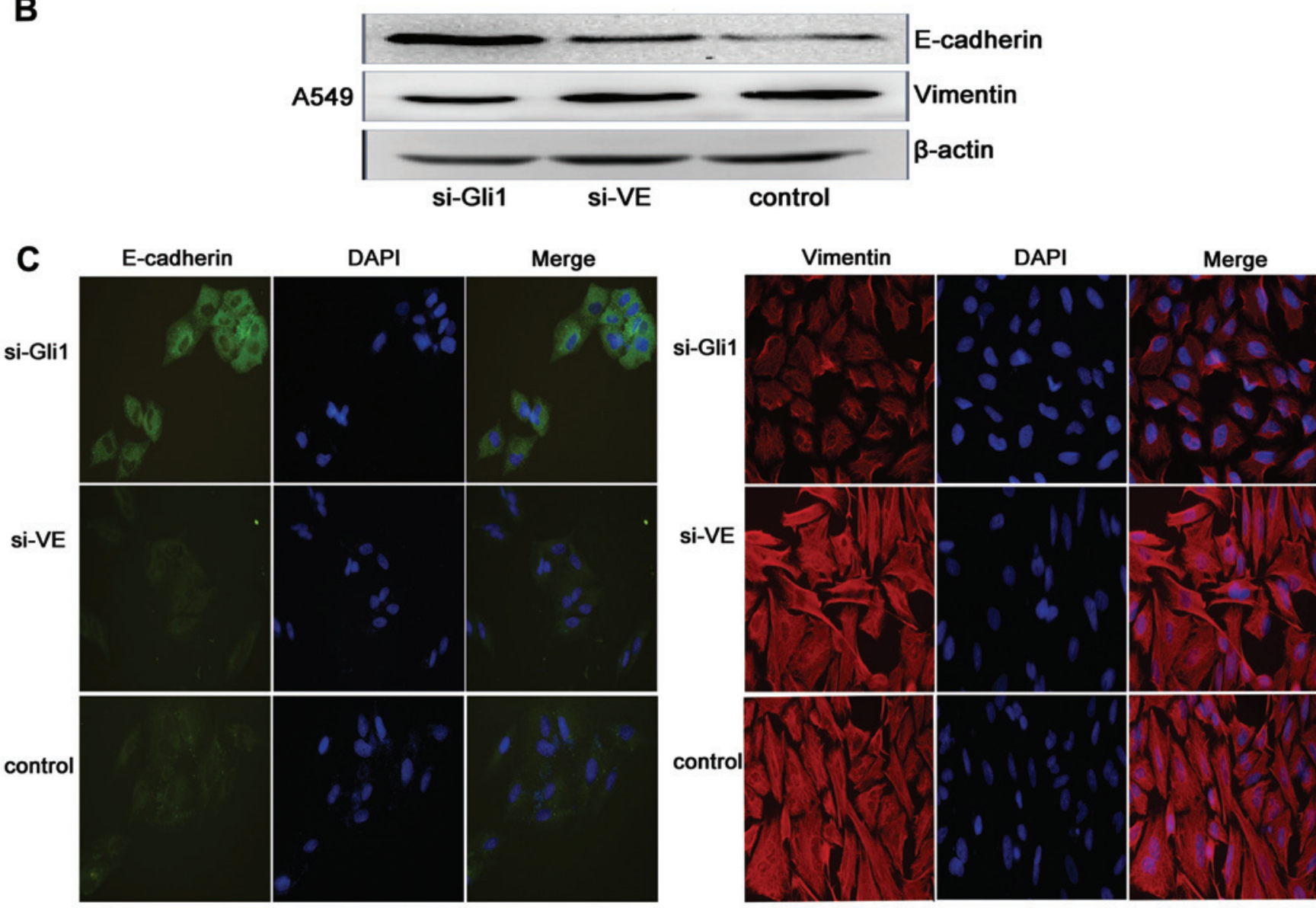

D

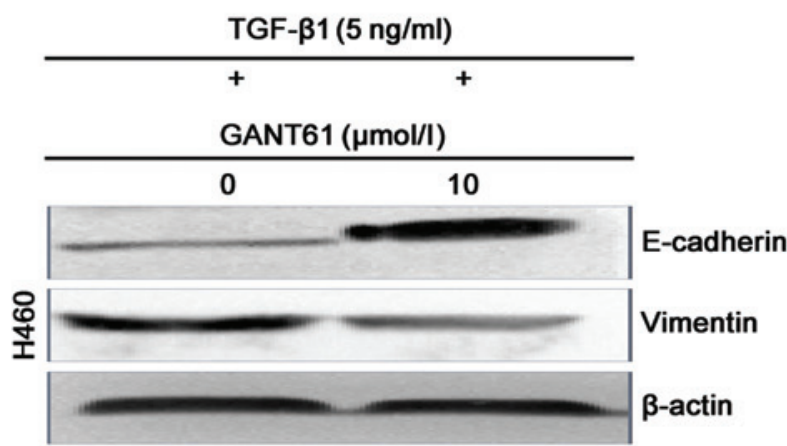

E

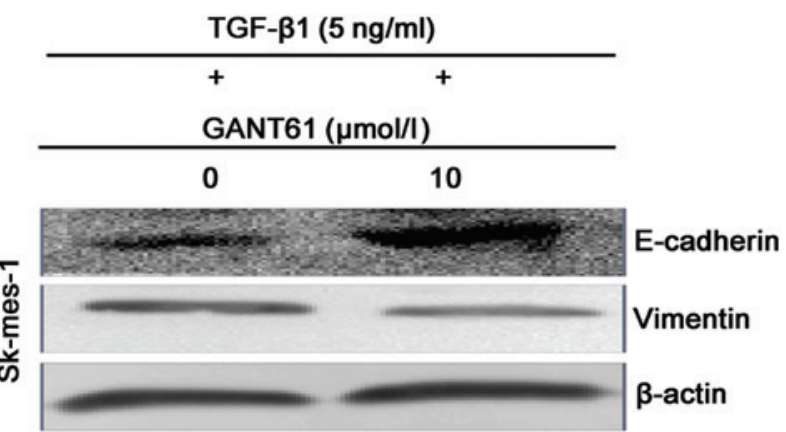

Figure 4. Effects of Gli1 on TGF- $\beta 1$-induced EMT of NSCLC cells. (A) Phase contrast microscopy used to assess the morphology of A549 cells 24 h subsequent to si-Gli1, si-VE or blank transfection $18 \mathrm{~h}$ following TGF- $\beta 1$-stimulation. (B) Western blot analysis and (C) immunofluorescence staining of E-cadherin, vimentin and $\beta$-actin levels $48 \mathrm{~h}$ subsequent to transfection. The immunofluorescence experiments were performed 3 times and images represent a magnification of $x 400$. Western blot analysis to assess E-cadherin and vimentin expression in (D) H460 and (E) SK-MES-1 cells treated with the Gli1 inhibitor GANT 61 $(10 \mu \mathrm{M})$ for $48 \mathrm{~h}$ and stimulated with $5 \mathrm{ng} / \mathrm{ml}$ TGF- $\beta 1$ for $48 \mathrm{~h}$. Gli1, glioma-associated oncogene homolog 1; TGF- $\beta 1$, transforming growth factor- $\beta 1$; EMT, epithelial-mesenchymal transition; NSCLC, non-small cell lung cancer; si-Gli1, Gli1 siRNA group; si-VE, nonspecific siRNA group. 
A

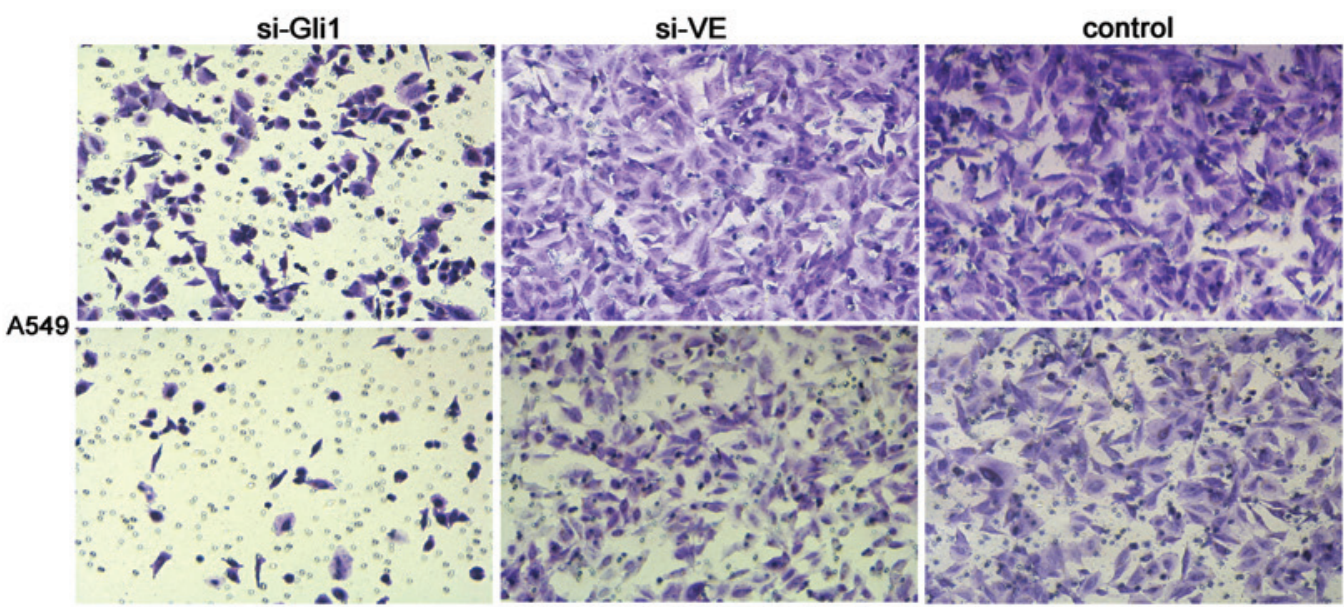

B

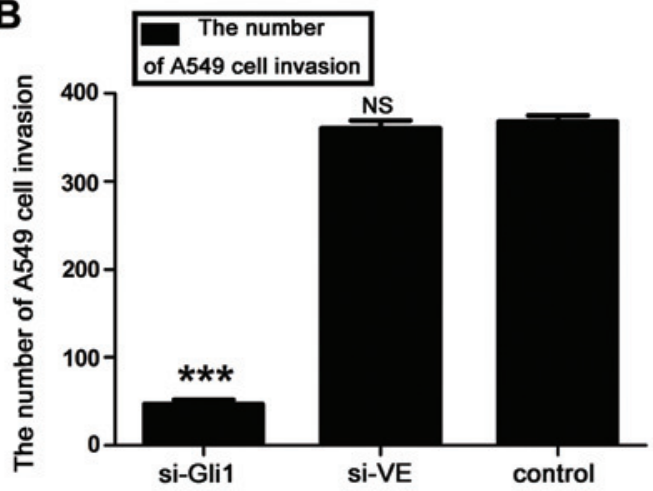

TGF- $\beta 1(5 \mathrm{ng} / \mathrm{ml})$

\section{D}

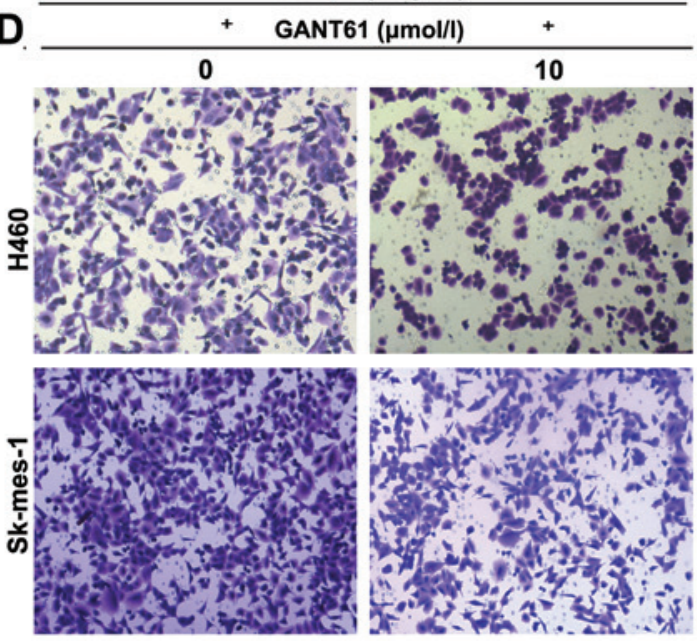

C

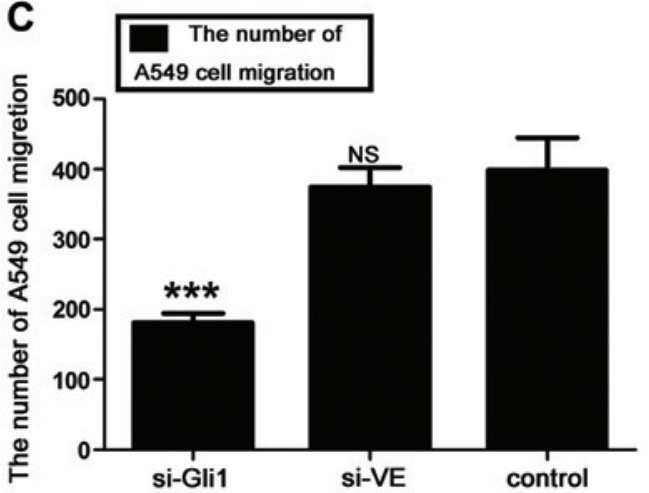

$\mathbf{E}$

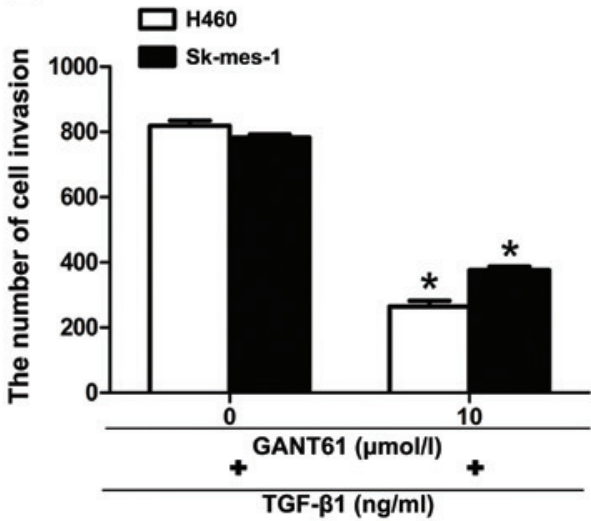

Figure 5. Inhibition of Gli1 reduced the invasive and migratory capacity of TGF- $\beta 1$-induced NSCLC cells. (A) Cells were seeded $48 \mathrm{~h}$ subsequent to si-Gli1, si-VE, or blank transfection into the upper transwell chambers, which were either pre-coated with $20 \mathrm{mg}$ Matrigel (invasion assay), or uncoated (migration assay). Following a 24-h resting period, cells which had migrated (upper panels) or invaded (lower panels) were stained with crystal violet and imaged with a phase contrast microscope (magnification, x100). Five fields were randomly chosen from each filter, and values representing the mean numbers of cells which had (B) invaded or (C) migrated were obtained. Each experiment was performed in triplicate. (D and E) Transwell Matrigel invasion assay results from TGF- $\beta 1$-stimulated H460 and SK-MES-1 cells treated with $10 \mu \mathrm{M}$ GANT 61. All values represent the mean number of cells, error bars represent the standard deviation. NS, not significant; ${ }^{*} \mathrm{P}<0.05,{ }^{* *} \mathrm{P}<0.005$ and ${ }^{* * *} \mathrm{P}<0.001$ vs. control. Gli1, glioma-associated oncogene homolog 1 ; TGF- $\beta 1$, transforming growth factor- $\beta 1$; NSCLC, non-small cell lung cancer; si-Gli1, Gli1 siRNA group; si-VE, nonspecific siRNA group.

to TGF- $\beta 1$ stimulation (Fig. 4A). The expression of EMT markers in TGF- $\beta 1$ following siRNA-mediated depletion of Gli1 was also assessed. Western blot and immunofluorescence analysis demonstrated that, compared with cells transfected with control siRNA, E-cadherin expression was elevated in cells transfected with Glil siRNA, while vimentin protein levels were reduced (Fig. 4B and C). The effects of pharmacological inhibition of Gli1 on TGF- $\beta 1$-induced EMT in H460 and SK-MES-1 cells were also investigated. An elevation of E-cadherin protein levels and a reduction of vimentin expression was observed following 48-h GANT 61 treatment in H460 and SK-MES-1 cells, compared with untreated cells 
(Fig. 4D and E). These results suggest that the downregulation of Gli1 inhibits TGF- $\beta 1$-induced EMT of NSCLC cells.

Downregulation of Glil reduces the invasive and migratory capacity of the TGF- $\beta 1$-stimulated NSCLC cells. Given the effects of Gli1 inhibition on the expression of EMT markers, the effect of Gli1 siRNA on the invasive and migratory abilities of TGF- $\beta 1$-induced A549 cells was investigated. Compared with cells transfected with non-specific control siRNA and untransfected cells, cells with Gli1 siRNA exhibited significantly reduced invasion and migration in a Transwell assay $(\mathrm{P}<0.001$; Fig. 5A-C), suggesting that Gli1 is required for migration in response to TGF- $\beta 1$. The effects of Gli1 inhibition on the invasive capacity of H460 and SK-MES-1 cells were also investigated. Suppression of Gli1 using GANT 61 significantly inhibited the ability of H460 and SK-MES-1 cells to invade through Matrigel compared with untreated cells $(\mathrm{P}<0.05$; Fig. 5D and E). These data suggest that Gli1 contributes to the enhanced migration and invasion of TGF- $\beta 1$-stimulated NSCLC cells.

\section{Discussion}

EMT is an important biological process that allows cancer cells to develop metastatic characteristics. One of the major alterations that occurs during EMT is the loss of the cell-cell adhesion molecule E-cadherin and overexpression of vimentin, N-cadherin and MMP-9 (6). In the current study, A549 NSCLC cells were demonstrated to undergo morphological alterations associated with EMT, following stimulation with TGF- $\beta 1$, in a dose-dependent manner. Following 48 -h TGF- $\beta 1$ stimulation, the A549, H460 and SK-MES-1 cells were observed to exhibit a mesenchymal phenotype, with elongated, spindle-shaped cells and a reduction in cell-cell contacts. These morphological alterations were accompanied by the downregulation of E-cadherin and upregulation of vimentin, which is consistent with classical EMT.

In addition to these morphological alterations, EMT is associated with increased motility and invasive ability. Consistent with this, the current study observed that TGF- $\beta 1$ treatment led to an increase in the migratory behavior of A549 cells compared with untreated cells in a wound healing assay. Furthermore, TGF- $\beta 1$ enhanced the invasive ability of H460 and SK-MES-1 cells in a Transwell Matrigel invasion assay. Taken together, these data indicate that TGF- $\beta 1$ promotes EMT and its associated metastatic behavior in NSCLC cells.

To investigate the molecular mechanism of TGF- $\beta 1$-induced EMT in NSCLC, the current study focused on Gli1. Notably, TGF- $\beta 1$ stimulation was observed to upregulate Gli1 expression in A549 cells in a dose-dependent manner, as assessed by western blotting, RT-qPCR and immunofluorescence analysis, suggesting that Gli1 may serve an important function in TGF- $\beta 1$-induced EMT. Inhibition of Gli1 using siRNA or the Gli1 inhibitor GANT 61 prevented morphological alterations in NSCLC cells following TGF- $\beta 1$ stimulation. Furthermore, inhibition of Glil attenuated the induction of the mesenchymal marker vimentin, and upregulated the epithelial marker E-cadherin following TGF- $\beta 1$ treatment. In addition, inhibition of Gli1 reduced the migratory and invasive capacity of NSCLC cells. These results suggest that Glil is important in the induction of EMT by TGF- $\beta 1$ and that inhibition of Gli1 may reverse the EMT phenotype in NSCLC cells, thus potentially reducing metastasis.

TGF- $\beta 1$ is a multifunctional cytokine that is closely associated with cell growth, fibrosis and tumorigenesis. It is also able to promote EMT and tumor cell metastasis $(11,22)$, and this has been demonstrated in several cancer cell lines (23-26). The Gli1 protein is a zinc finger transcription factor that is activated by the Hh signaling pathway, which involves Hh proteins, the Patched protein, the Smoothened (Smo) protein and the five-zinc finger Gli transcription factor family (Gli1, Gli2 and Gli3) (27,28). Gli1 and Gli2 act as the main activators of Hh-target genes, while Gli3 acts as a repressor of Hh target genes $(29,30)$. The $\mathrm{Hh}$ signaling pathway is implicated in developmental processes and tumor malignancies $(31,32,34)$, and the Gli family of transcription factors mediate a number of important cellular processes, including EMT, migration, metastasis and tumorigenesis (21). In NSCLC specifically, Gli1 has been demonstrated to be elevated in tumor tissue samples and NSCLC cells lines $(13,33)$. In addition, upregulation of $\mathrm{Hh}$ signaling has been indicated to contribute to TGF- $\beta 1$-induced EMT in NSCLC cells (19). These data are consistent with the observations of the current study, demonstrating that Gli1 levels are elevated in TGF- $\beta 1$-stimulated NSCLC cells that have undergone EMT, thus it is suggested that Glil is important in EMT downstream of TGF- $\beta 1$.

The current study suggests that Hh signaling, and Gli1 in particular, may provide a novel therapeutic target in NSCLC. As the Gli1 transcription factor mediates the terminal effects of the Hh pathway, the upstream positive regulator of Gli1 (Smo) has been investigated as a therapeutic target, with several Smo-targeted small molecule inhibitors currently undergoing clinical trials. One Smo-targeted small molecule inhibitor, vismodegib (GDC-0449), has been demonstrated in phase I clinical trials to be suitable for the treatment of multiple types of cancer (35). In addition to Smo, other signaling pathways, such as oncogenic epidermal growth factor receptor-RAS-protein kinase B (AKT) signaling have been demonstrated to activate Gli1 (36). In particular, the PI3K/AKT and mitogen-activated protein kinase/extracellular-signal-regulated kinase (ERK)1/2 signaling pathways also regulate TGF- $\beta 1$-induced EMT in A549 cells (37). However, the precise role Gli1 in PI3K and ERK signaling remains to be fully elucidated.

In conclusion, the results of the current study indicate that the loss of Gli1 in NSCLC cells dramatically attenuates TGF- $\beta 1$-induced EMT. Gli1 appears to be required for the phenotypic alterations, in addition to the enhancement of motility and invasion associated with TGF- $\beta 1$-induced EMT. The results of the present study suggest that inhibition of Gli1 may serve as a useful strategy to target metastatic disease in patients with NSCLC. Additionally, as EMT affects the sensitivity of NSCLC cell lines to common therapeutic agents including erlotinib, cisplatin and paclitaxel (38-40), targeting Gli1 may improve the efficacy of these therapies. EMT also affects the response to radiotherapy, including promoting radiation-induced fibrosis and post-radiotherapy-associated metastasis (40), which is suggested to occur through the loss of E-cadherin $(41,42)$. Therefore, reversal of EMT via Glil inhibition may potentially resensitize NSCLC cells to chemotherapy and radiation, which would contribute to improved prognosis for patients. 


\section{Acknowledgements}

The authors thank Ms. Zhu Yang and Mr. Tao Yu for their academic assistance. The current study was supported by the College of Life Science and Biological Engineering of Chongqing Medical University (Chongqing, China).

\section{References}

1. Cagle PT, Allen TC, Dacic S, et al: Revolution in lung cancer: new challenges for the surgical pathologist. Arch Pathol Lab Med 135: 110-116, 2011.

2. Juergens $\mathrm{R}$ and Brahmer J: Targeting the epidermal growth factor receptor in non-small-cell lung cancer: who, which, when, and how? Curr Oncol Rep 9: 255-264, 2007.

3. Alberg AJ, Ford JG and Samet JM; American College of Chest Physicians: Epidemiology of lung cancer: ACCP evidence-based clinical practice guidelines (2nd edition). Chest 132 (Suppl): 29S-55S, 2007.

4. Gavert N and Ben-Ze'ev A: Epithelial-mesenchymal transition and the invasive potential of tumors. Trends Mol Med 14: 199-209, 2008.

5. Thiery JP, Acloque H, Huang RY and Nieto MA: Epithelial-mesenchymal transitions in development and disease. Cell 139: 871-890, 2009.

6. Prudkin L, Liu DD, Ozburn NC, et al: Epithelial-to-mesenchymal transition in the development and progression of adenocarcinoma and squamous cell carcinoma of the lung. Mod Pathol 22: 668-678, 2009.

7. Li LP, Lu CH, Chen ZP, et al: Subcellular proteomics revealed the epithelial-mesenchymal transition phenotype in lung cancer. Proteomics 11: 429-439, 2011.

8. Wang G, Dong W, Shen H, et al: A comparison of Twist and E-cadherin protein expression in primary non-small-cell lung carcinoma and corresponding metastases. Eur J Cardiothorac Surg 39: 1028-1032, 2011.

9. Pirozzi G, Tirino V, Camerlingo R, et al: Epithelial to mesenchymal transition by TGF $\beta-1$ induction increases stemness characteristics in primary non small cell lung cancer cell line. PLoS One 6: e21548, 2011.

10. Soltermann A, Tischler V, Arbogast S, et al: Prognostic significance of epithelial-mesenchymal and mesenchymal-epithelial transition protein expression in non-small cell lung cancer. Clin Cancer Res 14: 7430-7437, 2008.

11. Lee JM, Dedhar S, Kalluri R, Thompson EW: The epithelial-mesenchymal transition: new insights in signaling, development, and disease. J Cell Biol 172: 973-981, 2006.

12. Zhang HJ, Wang HY, Zhang HT, et al: Transforming growth factor- $\beta 1$ promotes lung adenocarcinoma invasion and metastasis by epithelial-to-mesenchymal transition. Mol Cell Biochem 355: 309-314, 2011

13. Gialmanidis IP, Bravou V, Amanetopoulou SG, Varakis J, Kourea $\mathrm{H}$ and Papadaki $\mathrm{H}$ : Overexpression of hedgehog pathway molecules and FOXM1 in non-small cell lung carcinomas. Lung Cancer 66: 64-74, 2009.

14. Stecca B and Ruiz I Altaba A: Context-dependent regulation of the GLI code in cancer by HEDGEHOG and non-HEDGEHOG signals. J Mol Cell Biol 2: 84-95, 2010.

15. Aokage K, Ishii G, Ohtaki Y, et al: Dynamic molecular changes associated with epithelial-mesenchymal transition and subsequent mesenchymal-epithelial transition in the early phase of metastatic tumor formation. Int J Cancer 128: 1585-1595, 2011

16. Kasai H, Allen JT, Mason RM, Kamimura T and Zhang Z: TGF-betal induces human alveolar epithelial to mesenchymal cell transition (EMT). Respir Res 6: 56, 2005.

17. Kim JH, Jang YS, Eom KS, et al: Transforming growth factor beta1 induces epithelial-to-mesenchymal transition of A549 cells. J Korean Med Sci 22: 898-904, 2007.

18. Sporn MB: The war on cancer. Lancet 347: 1377-1381, 1996.

19. Maitah MY, Ali S, Ahmad A, Gadgeel S and Sarkar FH: Up-regulation of sonic hedgehog contributes to TGF- $\beta 1$-induced epithelial to mesenchymal transition in NSCLC cells. PLoS One 6: e16068, 2011.

20. Zhu H and Lo HW: The human glioma-associated oncogene homolog 1 (GLI1) family of transcription factors in gene regulation and diseases. Curr Genomics 11: 238-245, 2010.
21. Zheng X, Vittar NB, Gai X, et al: The transcription factor GLI1 mediates TGF $\beta 1$ driven EMT in hepatocellular carcinoma via a SNAI1-dependent mechanism. PLoS One 7: e49581, 2012.

22. Massagué J, Blain SW and Lo RS: TGFbeta signaling in growth control, cancer, and heritable disorders. Cell 103: 295-309, 2000.

23. Ko H, So Y, Jeon $\mathrm{H}$, Jeong $\mathrm{MH}$, et al: TGF- $\beta 1$-induced epithelial-mesenchymal transition and acetylation of Smad2 and Smad3 are negatively regulated by EGCG in human A549 lung cancer cells. Cancer Lett 10: 205-213, 2013.

24. Gunaratne A, Thai BL and Di Guglielmo GM: Atypical protein kinase $\mathrm{C}$ phosphorylates Par6 and facilitates transforming growth factor $\beta$-induced epithelial-to-mesenchymal transition. Mol Cell Biol 33: 874-886, 2013.

25. Liu LC, Tsao TC, Hsu SR, Wang HC, Tsai TC, Kao JY and Way TD: EGCG inhibits transforming growth factor- $\beta$-mediated epithelial-to-mesenchymal transition via the inhibition of Smad2 and Erk1/2 signaling pathways in nonsmall cell lung cancer cells. J Agric Food Chem 60: 9863-9873, 2012.

26. Cao M, Seike M, Soeno C, et al: MiR-23a regulates TGF- $\beta$-induced epithelial-mesenchymal transition by targeting E-cadherin in lung cancer cells. Int J Oncol 41: 869-875, 2012.

27. Pasca di Magliano M and Hebrok M: Hedgehog signalling in cancer formation and maintenance. Nat Rev Cancer 3: 903-911, 2003.

28. Ruel L, Rodriguez R, Gallet A, Lavenant-Staccini L and Thérond PP: Stability and association of Smoothened, Costal2 and Fused with Cubitus interruptus are regulated by Hedgehog. Nat Cell Biol 5: 907-913, 2003.

29. Wang B, Fallon JF and Beachy PA: Hedgehog-regulated processing of Gli3 produces an anterior/posterior repressor gradient in the developing vertebrate limb. Cell 100: 423-434, 2000.

30. Bai CB, Stephen D and Joyner AL: All mouse ventral spinal cord patterning by hedgehog is Gli dependent and involves an activator function of Gli3. Dev Cell 6: 103-115, 2004.

31. Teglund S and Toftgård R: Hedgehog beyond medulloblastoma and basal cell carcinoma. Biochim Biophys Acta 1805: 181-208, 2010.

32. Katoh Y and Katoh M: Hedgehog target genes: mechanisms of carcinogenesis induced by aberrant hedgehog signaling activation. Curr Mol Med 9: 873-886, 2009.

33. Yuan Z, Goetz JA, Singh S, et al: Frequent requirement of hedgehog signaling in non-small cell lung carcinoma. Oncogene 26: 1046-1055, 2007.

34. Yoo YA, Kang MH, Lee HJ, et al: Sonic hedgehog pathway promotes metastasis and lymphangiogenesis via activation of Akt, EMT, and MMP-9 pathway in gastric cancer. Cancer Res 71: 7061-7070, 2011

35. LoRusso PM, Rudin CM, Reddy JC, et al: Phase I trial of hedgehog pathway inhibitor vismodegib (GDC-0449) in patients with refractory, locally advanced or metastatic solid tumors. Clin Cancer Res 17: 2502-2511, 2011.

36. Ruiz I Altaba A, Mas C and Stecca B: The Gli code: an information nexus regulating cell fate, stemness and cancer. Trends Cell Biol 17: 438-447, 2007.

37. Chen XF, Zhang HJ, Wang HB, et al: Transforming growth factor- $\beta 1$ induces epithelial-to mesenchymal transition in human lung cancer cells via PI3K/Akt and MEK/Erk1/2 signaling pathways. Mol Biol Rep 39: 3549-3556, 2012.

38. Yauch RL, Januario T, Eberhard DA, et al: Epithelial versus mesenchymal phenotype determines in vitro sensitivity and predicts clinical activity of erlotinib in lung cancer patients. Clin Cancer Res 11: 8686-8698, 2005.

39. Shintani Y, Okimura A, Sato K, et al: Epithelial to mesenchymal transition is a determinant of sensitivity to chemoradiotherapy in non-small cell lung cancer. Ann Thorac Surg 92: 1794-1804, 2011.

40. Jung JW, Hwang SY, Hwang JS, Oh ES, Park S, Han IO: Ionising radiation induces changes associated with epithelial-mesenchymal transdifferentiation and increased cell motility of A549 lung epithelial cells. Eur J Cancer 43: 1214-1224, 2007.

41. Zhou YC, Liu JY, Li J, et al: Ionizing radiation promotes migration and invasion of cancer cells through transforming growth factor-beta-mediated epithelial-mesenchymal transition. Int J Radiat Oncol Biol Phys 81: 1530-1537, 2011.

42. Theys J, Jutten B, Habets R, et al: E-Cadherin loss associated with EMT promotes radioresistance in human tumor cells. Radiother Oncol 99: 392-397, 2011. 